\title{
OPTIMIZATION OF PROCESS PARAMETERS FOR VINEGAR PRODUCTION USING BANANA FERMENTATION
}

\author{
Pooja Saha $^{1}$, Soumitra Banerjee ${ }^{2}$ \\ ${ }^{1,2}$ Department of Food Technology, Under TIFAC-CORE Activity, Techno India Salt Lake, Kolkata - 700091, India \\ poojasaha1710@gmail.com,bitsouban04@yahoo.co.in
}

\begin{abstract}
Vinegar fermentation was essentially a two-step process comprising the anaerobic conversion of sugars to ethanol $\left(\mathrm{C}_{2} \mathrm{H}_{5} \mathrm{OH}\right)$ and the aerobic oxidation of ethanol to acetic acid $\left(\mathrm{CH}_{3} \mathrm{CO}_{2} \mathrm{H}\right)$. It was to be found that vinegar could be successfully produced from the juice extracted from banana using yeast and Acetobacter. Banana fruit pulp was a suitable raw material for ethanol production by fermentation and for vinegar production by this ethanol.

The present study indicates that a relatively good yield of ethanol and acetic acid can be obtained after optimization of certain physical conditions for fermentation. For Banana Alcohol, the highest alcohol level was $7.77 \%$ at $10 \%$ sugar level, $8 \%$ yeast cell concentration for 48 hrs. at $28^{\circ} \mathrm{C}$. For Banana Vinegar, the maximum acidity was obtained $4.67 \%$ at $7.77 \%$ of alcohol level, $15 \%$ of A. aceti cell concentration for 72 hrs. at $37^{\circ} \mathrm{C}$.

The Response Surface Methodology (RSM) was adopted to optimize the process parameters like Alcohol content, A.aceti cell concentration and time for the vinegar fermentation using Acetobactor aceti (MTCC 2623) using statistical software, Design Expert (version 8.0.7.1., StatEase, Inc., Minneapolis, USA). The statistical analyses and the closeness of the experimental results and model predictions highlight the reliability of the regression model.
\end{abstract}

Keywords: Fermentation, Vinegar, Ethanol, Acetobactor aceti, Response Surface Methodology.

\section{INTRODUCTION}

Vinegar was known worldwide as a seasoning or food preserving agent. Vinegar is defined as " a liquid fit for human consumption, produced from a suitable raw material of agricultural origin, containing starch, sugars, or starch and sugars by the process of double fermentation, alcoholic and acetous, and contains a specified amount of acetic acid" (Joint FAO/ WHO Food Standards Programme, 1987).

Vinegar, a traditional acidic condiment, is widely produced from rice, malt, apples, wine and various other agricultural material (Ciani, 1998; Horiuchi et. al., 1999). Vinegar production ranges from traditional methods employing wood casks and surface culture to submerged fermentation in acetators (Morales et al 2001).Vinegar fermentation is essentially a two stage process, being the first one the anaerobic conversion of fermentable sugars to ethanol by yeasts, usually Saccharomyces species, and the second the aerobic oxidation of ethanol to acetic acid by bacteria, usually Acetobacter species (Adams, 1998; Horiuchi et. al., 2000). Acetic acid yield from fermented sugar is approximately $40 \%$, with the remaining sugar metabolites either lost to volatilization or converted into other compounds. Acid yield improvements can be achieved using high rates aeration during continuous production (Ghommidh et al 1986).
Vinegar bacteria, also called Acetic Acid Bacteria (AAB), are members of the genus Acetobacter and characterized by their ability to convert ethyl alcohol, $\mathrm{C}_{2} \mathrm{H}_{5} \mathrm{OH}$, into acetic acid, $\mathrm{CH}_{3} \mathrm{CO}_{2} \mathrm{H}$, by oxidation as shown below:

$$
\mathbf{2}_{2} \mathrm{H}_{5} \mathrm{OH} \stackrel{\text { Anaerobic }}{\longrightarrow} 2 \mathrm{CH}_{3} \mathrm{CHO} \stackrel{\text { Aerobic }}{\longrightarrow} 2 \mathrm{CH}_{3} \mathrm{CO}_{2} \mathrm{H}+2 \mathrm{H}_{2} \mathrm{O}
$$

Vinegar traditionally has been used as a food preservative. Whether naturally produced during fermentation or intentionally added, vinegar retards microbial growth and contributes sensory properties to a number of foods. The wide diversity of products containing vinegar (sauces, ketchup, mayonnaise, etc.) and the current fall in wine consumption have favored an increase in vinegar production (De Ory et al 2002).

According to FDA (Food and Drug Administration, USA), vinegar as a sour solution, contains not less than 4 grams of acetic acid in 100 cubic centimeters at $20^{\circ} \mathrm{C}$ that is produced through alcoholic and successively acetic fermentation of sugary and starchy substrates. Earlier processes used for making vinegar were the Orleans process (which is also known as the slow process), the quick process (which is also called the generator process), and the submerged culture 
process. The quick process and submerged culture process were developed and are used for commercial vinegar production today. Further processing of vinegar, following substrate conversion to acetic acid may include filtration, clarification distillation and pasteurization at $165.2^{\circ} \mathrm{F}\left(74^{\circ} \mathrm{C}\right)$ before it is bottled. Acetic acid concentration in vinegar may be expressed using the term "grain".

India is leading the world in the production of bananas. Mostly in India, Tamil nadu is the state produces the highest quantity of bananas. Due to a high rate of productivity of bananas in India they are easily available and available at low prices in the market. As bananas have a short shelf-life, there is a rapid rate of deterioration of this fruit (Akubor et al.,2003). Banana (Musa sp.) is a large perennial herb with leaf sheaths that form trunk-like pseudostem. It is rich in vitamin B6, which helps fight infection and is essential for the synthesis of heme-the iron containing part of haemoglobin. Banana is also rich in potassium and is a great source of fibre. A good quality alcoholic base for producing vinegar containing 5-6\% acetic acid was obtained. Simmonds (1966) reported that vinegar has been prepared by fermenting a mash of banana pulp and peel. Vinegar production from banana may enhance minimize cost of production and eco-friendly.

Traditionally ethanol has been produced by batch fermentation; employing Saccharomyces cerevesiae the name first applied by Meyen (1838) to distinguish beer yeasts from those isolated from other alcoholic beverages is still a major concern of all the researchers in the field. Yeasts are the only organisms currently used for large scale industrial ethanol production. Many of these newly developed bioprocesses for ethanol are mainly aimed at to enhance the productivity by employing high cell densities in the fermentor. It has been well recognized that alcoholic fermentation are limited due to the inhibitory effects of both substrate and product.

An efficient ethanol production requires four components: fermentable carbohydrates, anefficient yeast strain, a few nutrients and simple culture conditions. In this experiment, Saccharomyces cerevisiae yeast is used to convert glucose into ethyl alcohol. The yeast cell contains enzyme catalysts that provide an energetically favorable pathway for the reaction. Acetic fermentation is the next step in alcoholic fermentation, where alcohol molecules are oxidized into acetic acid molecules by the action of Acetobacter aceti bacteria, giving it the characteristic vinegar taste.

Response surface methodology (RSM) has been successfully used to model and optimize biochemical and biotechnological processes related to food systems. This methodology is employed to optimize media for Acetic acid fermentation.

\subsection{OBJECTIVE OF THE PROJECT}

$>$ To produce vinegar from banana which provides more practical feasibility due to its low cost

$>$ To optimize the conditions of fermentation for the production of banana juice vinegar.

$>$ to verify the effects of the initial concentrations of ethanol and acetic acid as two independent variables on process yield and productivity

$>$ to process optimization by the statistical design of experiments

$>$ To optimize of the different factors that play an important role in banana juice vinegar production.

\section{MATERIALS AND METHODS}

\subsection{BANANA ALCOHOL PRODUCTION}

\subsubsection{SOURCE OF BANANAS}

The bananas used in this study were variety 'Singhapuri' (Musa cavendishi) obtained from local markets in Kolkata, West Bengal, India. The bananas were selected according to the required degree of ripeness needed at a time of purchase. Occasionally, the bananas continued to ripen at a room temperature until the proper degree of ripeness was obtained.

\subsubsection{PREPARATION OF BANANA JUICE}

Several bananas were selected at random to be analyzed. The whole fruits were weighed and peeled. The fruits were then weighed. The components were hand chopped, crushed, sampled and immediately frozen until analyzed. However, the stored samples were utilized within $24 \mathrm{~h}$ of collection.

\subsubsection{PRE-TREATMENT OF BANANA SAMPLES}

Moisture content in the raw banana samples and banana pulp of was determined by drying in oven at $105^{\circ} \mathrm{C}$ for $2 \mathrm{~h}$. The titration method of Lane and Eynonl is used to determine the sugars content of banana juice and after pectinase addition, the total sugar content of banana juice. The bananas were crushed in mixer and the pulp was adjusted to $15^{\circ}$ Brix (concentration of soluble solids) by the addition of distillated water. The $\mathrm{pH}$ content of the raw banana samples and the banana pulp was estimated by the $\mathrm{pH}$ paper.

\subsubsection{DEPECTINISE THE PECTINASE MATERIAL (PECTIN SUBSTANCES) OF BANANA PULP BY THE USE OF PECTINASE ENZYME}

A sequential working was done on the activity of the pectinase enzyme on the banana pulp which was very much bulky. To obtain a clear juice from that bulky material, pectinase enzyme was treated in very minute quantity $(0.0003 \%) \mathrm{w} / \mathrm{v}$ and the banana pulp was then incubated for about 6 hours at a 
temperature of 38 degree centigrade with occasional stirring. A work had been done by taking of $0.0001 \%(\mathrm{w} / \mathrm{v}), 0.0002 \%$ (w/v), $0.0003 \%(w / v), 0.0004 \%$ (w/v), $0.0005 \%$ (w/v). The best result was obtained at $0.0003 \%(\mathrm{w} / \mathrm{v})$ and maximum juice was extracted using this percentage of the pectinase enzyme. The $0.0001 \%$ and $0.0002 \%$ (w/v) showed a result with incomplete breakdown of the pectin substances in banana pulp and hence the juice remained as partially bulky and the juice extracted was less and more residues were obtained which showed that the deficiency of the enzyme for the breakdown of the pectinaceous material. And $0.004 \%$ and $0.0005 \%(\mathrm{w} / \mathrm{v})$ showed no difference in the volume of juice that was extracted by using the $0.0003 \%(\mathrm{w} / \mathrm{v})$ pectinase enzyme and also in no difference in the weight of the banana residue. The experiment showed that the pectinase enzyme remained unused in case of $0.004 \% \& 0.005 \%(\mathrm{w} / \mathrm{v})$. Hence, we lead to a conclusion that the exact amount of pectinase enzyme required to breakdown the pectic substances or the pectinaceous materials present in the banana pulp is $0.0003 \%$ $(w / v)$. Enzyme activity of the pectinase enzyme is 14 IU per gram.

\subsubsection{CULTURE MEDIUM PREPARATION AND INOCULUM \& INOCULATION}

In culture medium preparation, a pinch of active dry yeast (Saccharomyces cerevisiae) was added to the sterile luke warm water. Then it was kept for 10 mins. The yeast inoculum was used at $10 \%$ to inoculate sterilized YEPD broth (DW $1000 \mathrm{ml}$, Peptone 5gm, Yeast Extract 5gm, Dextrose 10gm, pH $5)$. Then these growth medium was kept for aeration at $28^{\circ} \mathrm{C}$ on a rotary shaker (200rpm) for $24 \mathrm{hrs}$ before performing the fermentaion.

\subsubsection{LABOTORY SCALE OF BANANA} ALCOHOL PRODUCTION

\section{Chart-1: FLOW CHART OF ALCOHOL FERMENTATION}

FERMENTATION MEDIUM PREPARED WITH BANANA JUICE

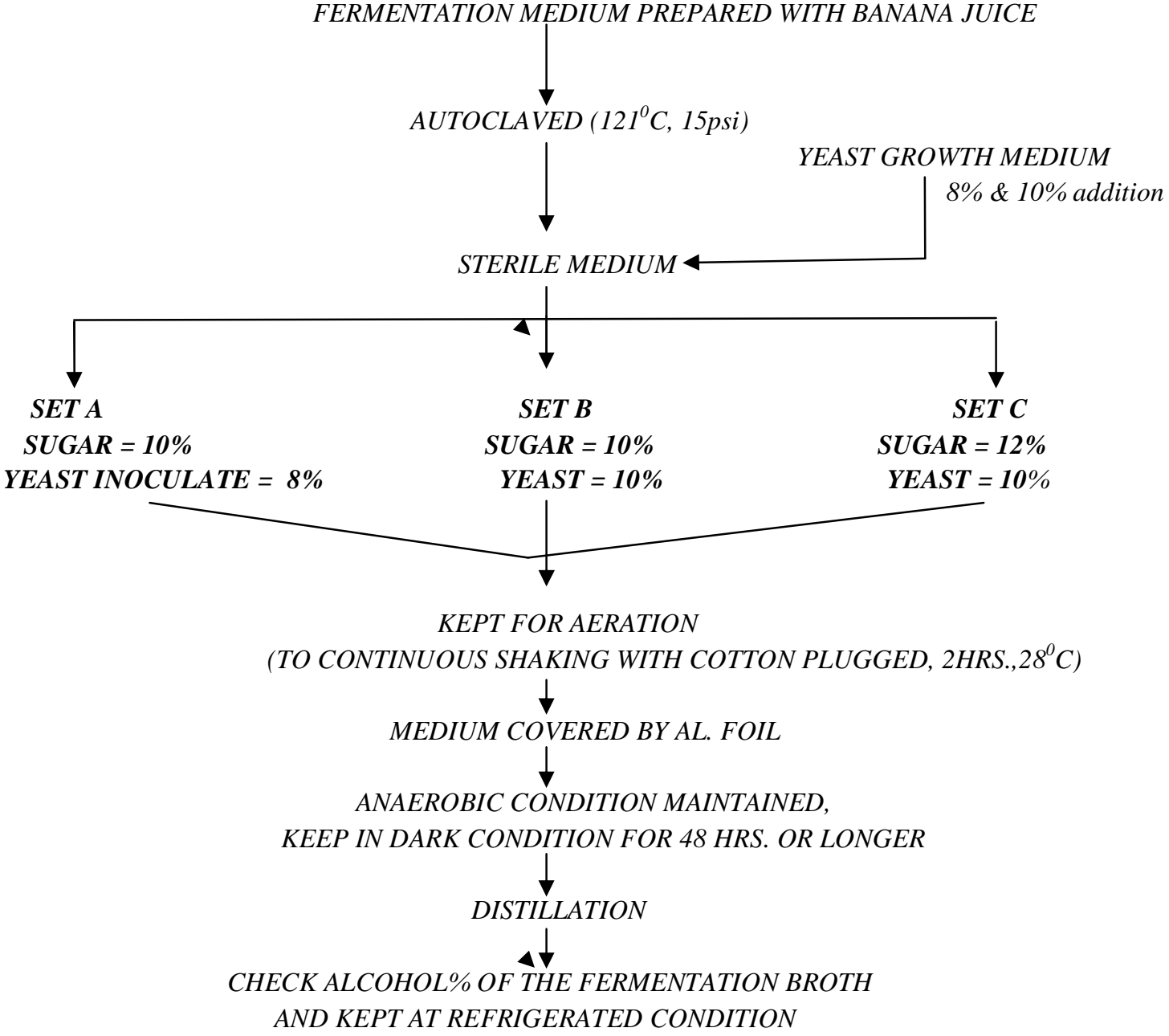




\subsubsection{DETERMINATION OF ALCOHOL} CONTENT OF BANANA FERMENTATION BROTH

The ethanol concentrations were estimated using the potassium dichromate redox titrations with Sodium Thiosulphate (this method was determined by College of Science, University of Canterbury, Christchurch, New Zealand (www.outreach.canterbury.ac.nz).

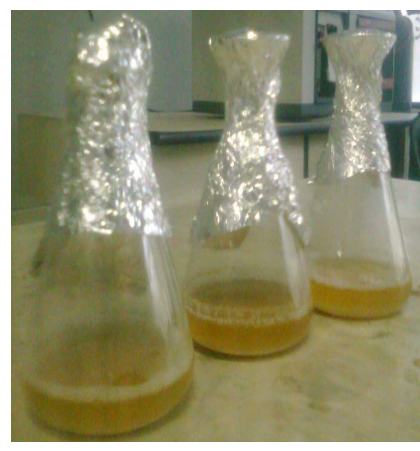

(1)

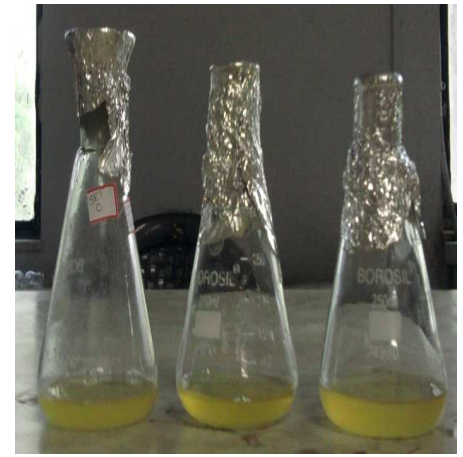

(2)
Fig- (1): After yeast cell inoculation and after 2 hrs. Shaking,

(2) Alcohol fermentation broth to allow anaerobic fermentation

\subsection{VINEGAR PRODUCTION}

\subsubsection{MICROORGANISMS, CULTURE MEDIA AND CULTIVATION}

Lyophilized culture of Acetobacter aceti (MTCC 2623) was obtained from the Microbial Type Culture Collection and Gene Bank (MTCC), Chandigarh, India. The strain was maintained on YPM agar medium (Distilled Water 1000ml, Yeast Extract 5gm, Peptone 3gm, Manitol 25gm, Agar 12gm, $\mathrm{pH}$ is Not adjusted) slant at $37^{\circ} \mathrm{C}$ for $24-48 \mathrm{hrs}$. Then one loop of cells from the slant was inoculated into YPM medium (Distilled Water $100 \mathrm{ml}$, Yeast Extract 0.5gm, Peptone 0.3gm, Manitol $2.5 \mathrm{gm}, \mathrm{pH}$ is not adjusted) and incubated on continuous shaking for $24-48 \mathrm{~h}$ at $37^{\circ} \mathrm{C}$, and then Acetobactor aceti growth medium was prepared and ready for inoculated to fermentation broth samples (SET A, SET B, SET C) to produce vinegar.

\section{Chart-2: FLOW CHART OF PRODUCTION OF VINEGAR}

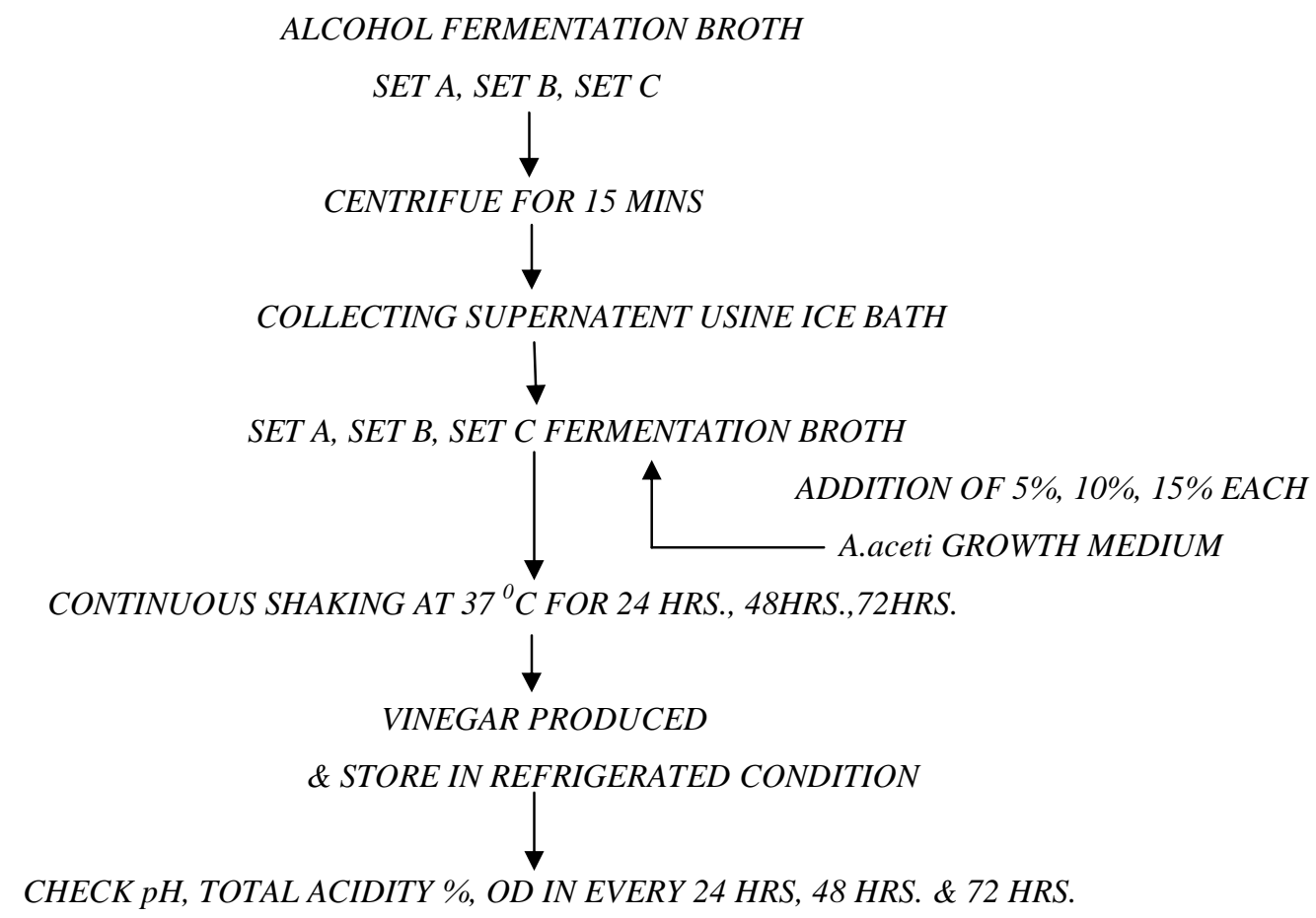




\subsubsection{ESTIMATION OF TOTAL ACIDITY \% OF VINEGAR}

Total acidity was evaluated by acid - base titration with standardized solution of $0.1 \mathrm{~N}$ sodium hydroxide, using phenolphthalein as a indicator and the results were expressed as acetic acid content (AOAC, 1990).

The stochiometry of the titration is given by:

$$
\mathrm{CH}_{3} \mathrm{COOH}+\mathrm{NaOH}=\mathrm{CH} 3 \mathrm{COONa}+\mathrm{H}_{2} \mathrm{O}
$$

The formula to calculate \% TA as acetic is as below:

$$
\begin{aligned}
& \% \mathrm{TA}=(\mathrm{ml} \text { of } \mathrm{NaOH}) \times(\mathrm{N} \text { of } \mathrm{NaOH}) \times(60.05) \backslash 10 \times \\
& \text { Sample Weight }
\end{aligned}
$$

The (w/v) \% acetic acid content was determined using the standard method for determination of acetic acid by Nielsen (1994).

\subsubsection{ESTIMATION OPTICAL DENSITY OF}

\section{VINEGAR FERMENTATION BROTH}

Optical density (OD) measurement of bacterial cultures is a common technique used in microbiology. Using a spectrophotometer to measure the optical density at $600 \mathrm{~nm}$ (OD600) of a bacterial culture to monitor bacterial growth has always been a central technique in microbiology. The OD of a bacterial culture is not a direct measure of bacterial growth number, but increase in turbidity does indicate bacterial growth.

\subsection{STATISTICAL DESIGN OF EXPERIMENTS}

\subsubsection{EXPERIMENTAL DESIGN}

The response surface methodology was applied to understand the interaction of various variables and then used to find the optimum concentration of the main medium components that affect the response.

A statistical program package, Design Expert (version 8.0.7.1., Stat-Ease Inc., Minneapolis, MN) was used for regression analysis of the data obtained and to estimate the coefficient of multivariate equation. This software was also used for the experimental design, data analysis and quadratic model building. Response surface and contour plots were generated to understand the interaction of different variables.

\subsubsection{CENTRAL COMPOSITE DESIGN (CCD)}

The first experimental CCD was carried out in order to identify and optimize the total acidity $\%$ and optical density of the production medium that have a significant effect on the vinegar production. The variables are coded according to the equation:

$$
X_{i}=\left(x_{i}-x_{o}\right) / \Delta x_{i}
$$

Where $X_{i}, x_{i}$ and $x_{0}$ are the coded value, uncoded value and the value at the center point respectively of the its test variable and $\Delta x_{i}$ is the step change value. The full experimental design in coded and uncoded form is given in Table 1 .

Table-1: Experimental Range And Levels Of The Independent Variables For Vinegar Production

\begin{tabular}{|c|c|c|c|}
\hline $\begin{array}{c}\text { INDEPENDENT } \\
\text { VARIABLES }\end{array}$ & $\mathbf{- 1}$ & $\mathbf{0}$ & $\mathbf{+ 1}$ \\
\hline $\begin{array}{c}\text { ALCOHOL } \\
\text { CONTENT , \% }\end{array}$ & 6.29 & 7.47 & 7.77 \\
\hline $\begin{array}{c}\text { INOCULUM } \\
\text { VOLUME , \% }\end{array}$ & 5 & 10 & 15 \\
\hline TIME, HRS. & 24 & 48 & 72 \\
\hline
\end{tabular}

The Behavior of this system was explained by the following second-degree polynomial equation:

$$
Y=\beta_{0}+\xi \beta_{i} X i+\xi \beta_{i i} X_{i}^{2}+\xi \beta_{i j} X_{i} X_{j}
$$

Where $\beta 0, B i(i=1,2,3)$, $\operatorname{Bii}(i=1,2,3)$ and $\operatorname{Bij}(i=1,2,3 ; j$ $=1,2,3$ and $i_{-} j$ ) are constants for the offset term, linear effects, quadratic effects and interactions effects, respectively. $X i(i=1,2,3)$ and $X j(j=1,2,3)\left(i_{-} j\right)$ are the process parameters and $Y$ is the response variable.

The graphical representation of these equations are called response surfaces, which was used to describe the individual and cumulative effects of the test variables on the response and to determine the mutual interactions between the test variables and their subsequent effect on the response. The correlation measures for the estimation of the regression equation are the multiple correlation coefficient $\boldsymbol{R}$ and the determination coefficient $\boldsymbol{R}^{2}$. ANOVA (Analysis of Variance) was used to test the significance and adequacy of the model. The $\boldsymbol{F}$ value (Fisher's variance ratio, $\mathrm{Sr} 2 / \mathrm{Se} 2$ ) was calculated from ANOVA. $F$ values much higher than unity indicate that the factors explain adequately the variation in the data about its mean and effects of estimated factors are true. The Studentt-distribution and the corresponding probability values ( $\boldsymbol{P}$ values) indicate the significance of each of the coefficient, which in turn governs the patterns of interactions between the variables. The smaller the value of $P$, the more significant is the corresponding coefficient.

Using statistical software, Design Expert (version 8.0.7.1., Start-Ease Inc ), $\boldsymbol{C C D}$ and $\boldsymbol{R S M}$ were used in the design of experiment and in the analysis of the results. 


\section{RESULTS AND DISCUSSION}

\subsection{BANANA ALCOHOL PRODUCTION}

Table-2: Physicochemical Analysis of Banana Samples

\begin{tabular}{|c|c|c|c|c|c|c|}
\hline SAMPLES & $\mathbf{p H}$ & MOISTURE & BRIX & $\begin{array}{c}\text { TOTAL } \\
\text { SUGAR }\end{array}$ & $\begin{array}{c}\text { PETAL SUGAR, } \\
\text { ADDITION }\end{array}$ & $\begin{array}{c}\text { AFTER PECTINASE } \\
\text { ADDITION }\end{array}$ \\
\hline $\begin{array}{c}\text { RAW } \\
\text { BANANA }\end{array}$ & 5 & $72.7 \%$ & - & - & - & - \\
\hline $\begin{array}{c}\text { BANANA } \\
\text { PULP }\end{array}$ & 6 & $73.2 \%$ & $15^{0}$ & $18.23 \%$ & $0.0003 \%$ & $24.68 \%$ \\
\hline
\end{tabular}

Table-3: Analysis of Banana Sample Broth

\begin{tabular}{|c|c|c|c|c|}
\hline Sample & $\begin{array}{c}\text { pH Before } \\
\text { Fermentation }\end{array}$ & $\begin{array}{c}\text { pH After } \\
\text { Fermentation }\end{array}$ & $\begin{array}{c}\text { Alcohol \% Of } \\
\text { Fermentation } \\
\text { Broth }\end{array}$ & $\begin{array}{c}\text { Residual Sugar \% } \\
\text { Of Fermentation } \\
\text { Broth }\end{array}$ \\
\hline SET A & 4 & 4 & 7.77 & 0 \\
\hline SET B & 4.5 & 4 & 7.47 & 0 \\
\hline SET C & 4 & 4 & 6.29 & 0 \\
\hline
\end{tabular}

$7.77 \%$ alcohol was produced by $8 \%$ yeast cell concentration at $28^{\mathrm{O}} \mathrm{C}, \mathrm{pH} 4.0$ and $10 \%$ sugar concentration for $48 \mathrm{hrs}$. But under the same time of 48 hrs., $10 \%$ yeastcell concentration produced $7.47 \%$ of alcohol. Alcohol production was gradually decreased with sugar concentration from $10 \%$ to $12 \%$. Though alcohol production takes place under resting condition, decrease in yeast cell concentration, more amount of sugar was utilized by yeast to be converted to alcohol. The distillation process was the most troublesome since it required the combination of many equipments which led to some malfunctions. From the above observations, we can conclude that the above process was highly suitable for industrial production of alcohol from banana fruits because the alcohol yield was low cost technology and also ecofriendly.

\subsection{VINEGAR PRODUCTION}

\subsubsection{PHYSICOCHEMICAL ANALYSIS}

The $\mathrm{pH}$, titratable acidity and optical density are very important parameters in the vinegar fermentation process.

Table-4: pH In Vinegar Fermentation Broth Measuring By pH Paper

\begin{tabular}{|c|c|c|c|c|}
\hline \multirow{3}{*}{ SAMPLE NAME } & $\begin{array}{c}\text { Acetobacter aceti } \\
\text { GROWTH } \\
\text { MEDIUM } \\
\text { INOCULATION }\end{array}$ & AFTER 24 HRS. & AFTER 48 HRS. & AFTER 72 HRS. \\
\hline \multirow{5}{*}{ SET A } & $5 \%$ & 5 & 4 & 4 \\
\cline { 2 - 5 } & $10 \%$ & 4 & 4 & 3 \\
\hline \multirow{5}{*}{ SET B } & $15 \%$ & 4 & 3 & 4 \\
\cline { 2 - 5 } & $5 \%$ & 5 & 4 & 4 \\
\hline \multirow{3}{*}{ SET C } & $10 \%$ & 4 & 3 & 4 \\
\cline { 2 - 5 } & $15 \%$ & 5 & 4 & 3 \\
\cline { 2 - 5 } & $10 \%$ & 4 & 4 & 4 \\
\hline
\end{tabular}


Table-5: Titrable Acidity \% in Vinegar Fermentation Broth

\begin{tabular}{|c|c|c|c|c|}
\hline SAMPLE NAME & $\begin{array}{c}\text { Acetobacter aceti } \\
\text { GROWTH MEDIUM } \\
\text { INOCULATION }\end{array}$ & $\begin{array}{c}\text { AFTER 24 HRS. } \\
\mathbf{\%}\end{array}$ & $\begin{array}{c}\text { AFTER 48 HRS. } \\
\text { \% }\end{array}$ & $\begin{array}{c}\text { AFTER 72 HRS. } \\
\text { \% }\end{array}$ \\
\hline \multirow{3}{*}{ SET A } & $\mathbf{5 \%}$ & 3.66 & 4.23 & 4.52 \\
\cline { 2 - 5 } & $\mathbf{1 0 \%}$ & 3.70 & 4.25 & 4.62 \\
\cline { 2 - 5 } & $\mathbf{1 5 \%}$ & 3.79 & 4.27 & 4.67 \\
\hline \multirow{3}{*}{ SET B } & $\mathbf{5 \%}$ & 3.28 & 4.13 & 4.40 \\
\cline { 2 - 5 } & $\mathbf{1 0 \%}$ & 3.39 & 4.17 & 4.43 \\
\hline \multirow{3}{*}{ SET C } & $\mathbf{1 5 \%}$ & 3.48 & 4.20 & 4.30 \\
\cline { 2 - 5 } & $\mathbf{5 \%}$ & 2.73 & 4.07 & 4.32 \\
\cline { 2 - 5 } & $\mathbf{1 0 \%}$ & 3.19 & 4.11 & 4.37 \\
\hline
\end{tabular}

Table-6: Optical Density in Vinegar Fermentation Broth

\begin{tabular}{|c|c|c|c|c|}
\hline SAMPLE NAME & $\begin{array}{c}\text { Acetobacter aceti } \\
\text { GROWTH MEDIUM } \\
\text { INOCULATION }\end{array}$ & \multicolumn{3}{|c|}{ ABSORBANCE AT } \\
\cline { 2 - 5 } & & AFTER 24 HRS. & AFTER 48 HRS & AFTER 72 HRS \\
& & & & 0.569 \\
\hline \multirow{3}{*}{ SET A } & $\mathbf{5 \%}$ & 0.389 & 0.449 & 0.699 \\
\cline { 2 - 5 } & $\mathbf{1 0 \%}$ & 0.519 & 0.579 & 1.245 \\
\cline { 2 - 5 } & $\mathbf{1 5 \%}$ & 1.065 & 1.128 & 1.026 \\
\hline \multirow{3}{*}{ SET B } & $\mathbf{5 \%}$ & 0.992 & 1.005 & 1.342 \\
\cline { 2 - 5 } & $\mathbf{1 0 \%}$ & 1.308 & 1.316 & 1.026 \\
\hline \multirow{3}{*}{ SET C } & $\mathbf{1 5 \%}$ & 1.318 & 1.326 & 1.459 \\
\cline { 2 - 5 } & $\mathbf{5 \%}$ & 1.001 & 1.012 & 1.459 \\
\cline { 2 - 5 } & $\mathbf{1 0 \%}$ & 1.434 & 1.445 & 1.441 \\
\hline
\end{tabular}

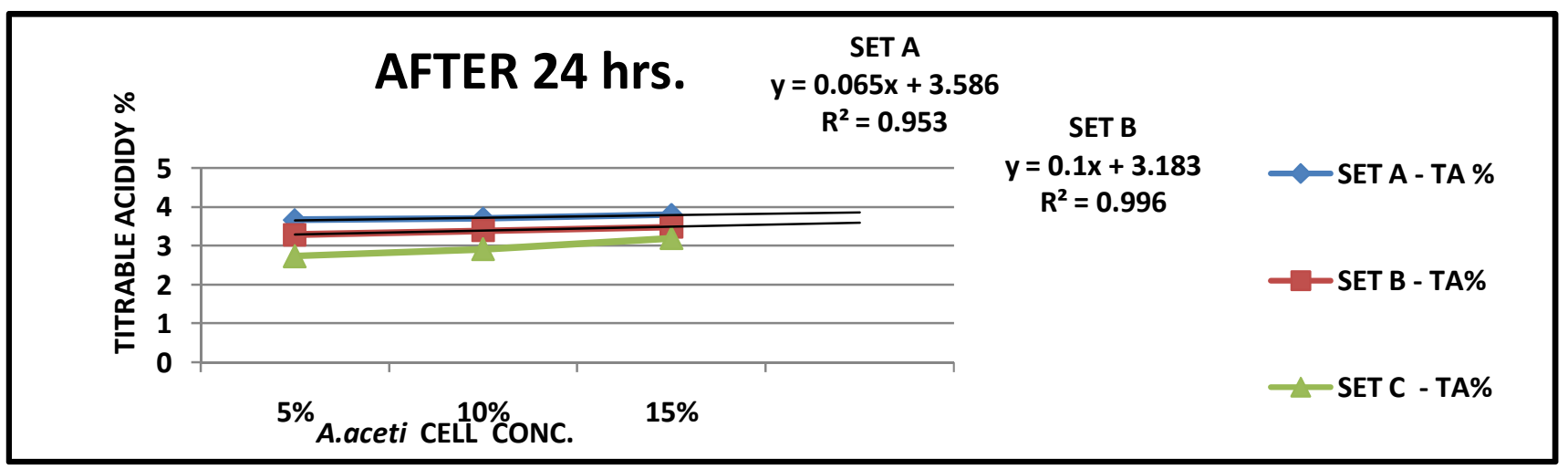

Chart-3: Effect Of Different A.aceti Cell Concentration On Titrable Acidity \% Of Samples Set A, Set B, Set C After 24 Hrs. 


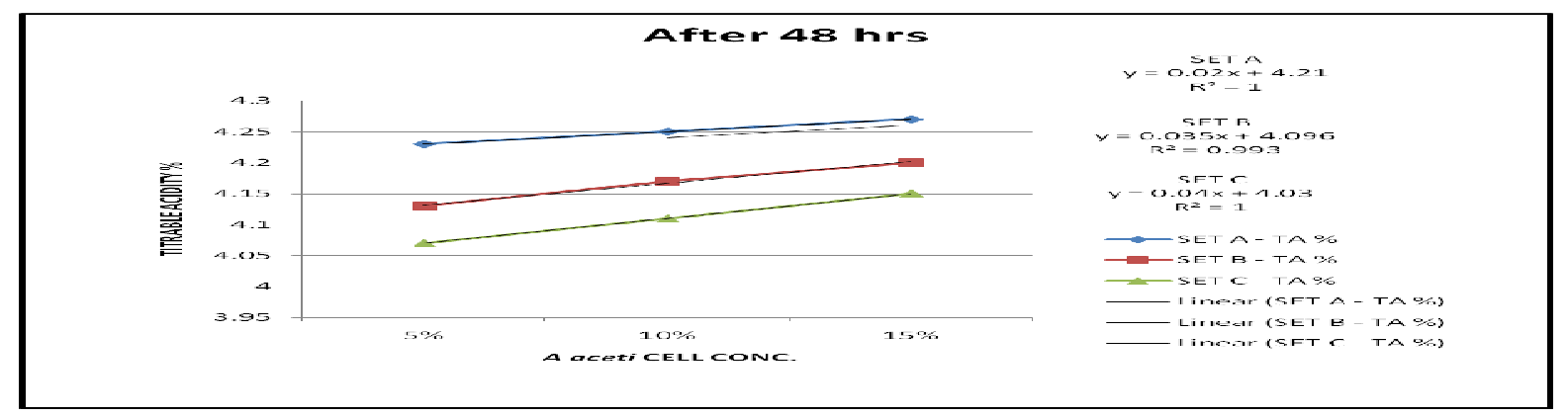

Chart-4: Effect of Different A.aceti Cell Concentration on Titrable Acidity \% of Samples Set A, Set B, Set C After 48 Hrs.

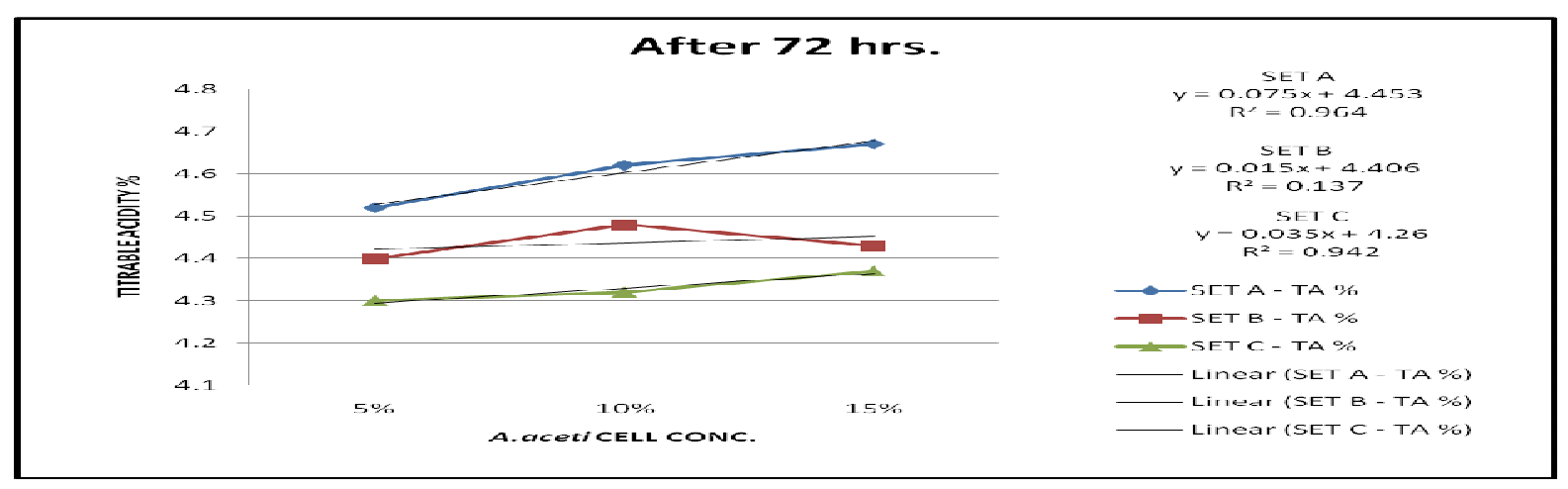

Chart-5: Effect Of Different A. aceti Cell Concentration on Titrable Acidity \% Of Samples Set A, Set B, Set C After 72 Hrs

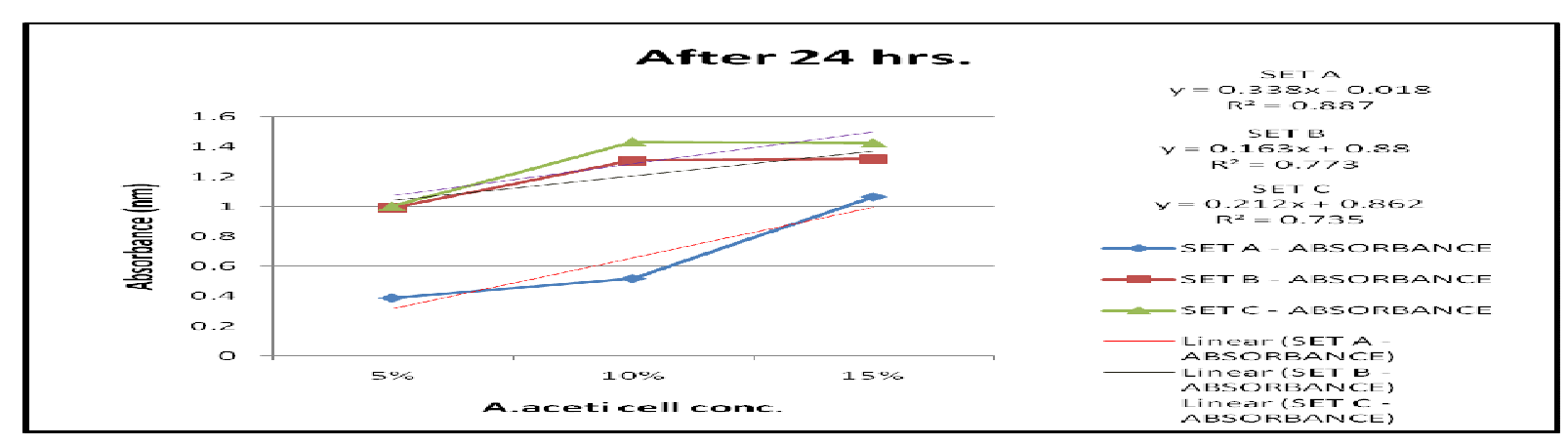

Chart-6: Effect Of Different A. aceti Cell Concentration On Optical Density Of Samples Set A, Set B, Set C After 24 Hrs.

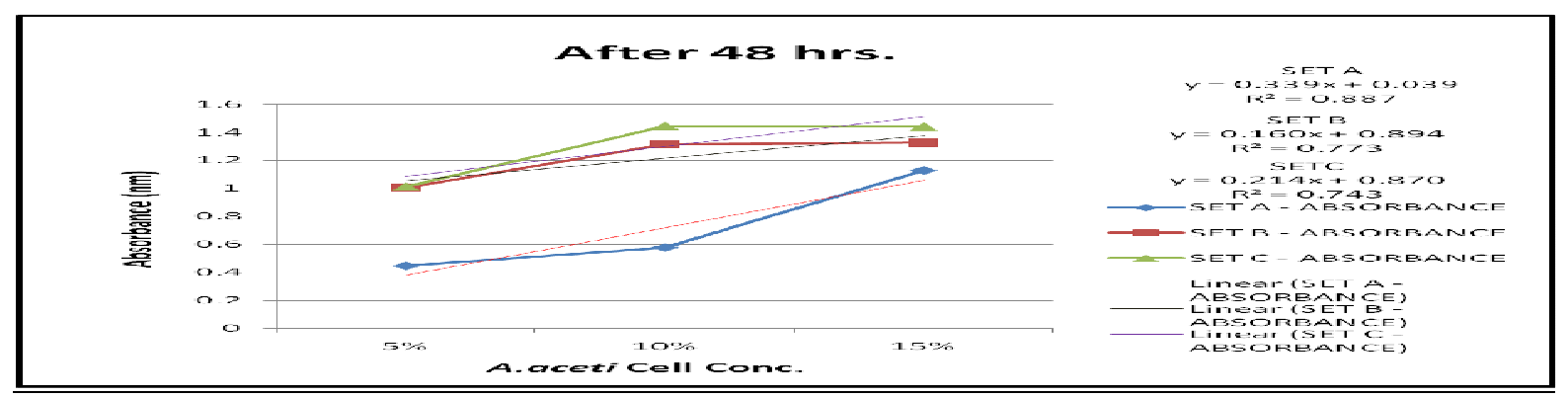

Chart-7: Effect Of Different A. aceti Cell Concentration on Optical Density of Samples Set A, Set B, Set C After 48 Hrs 


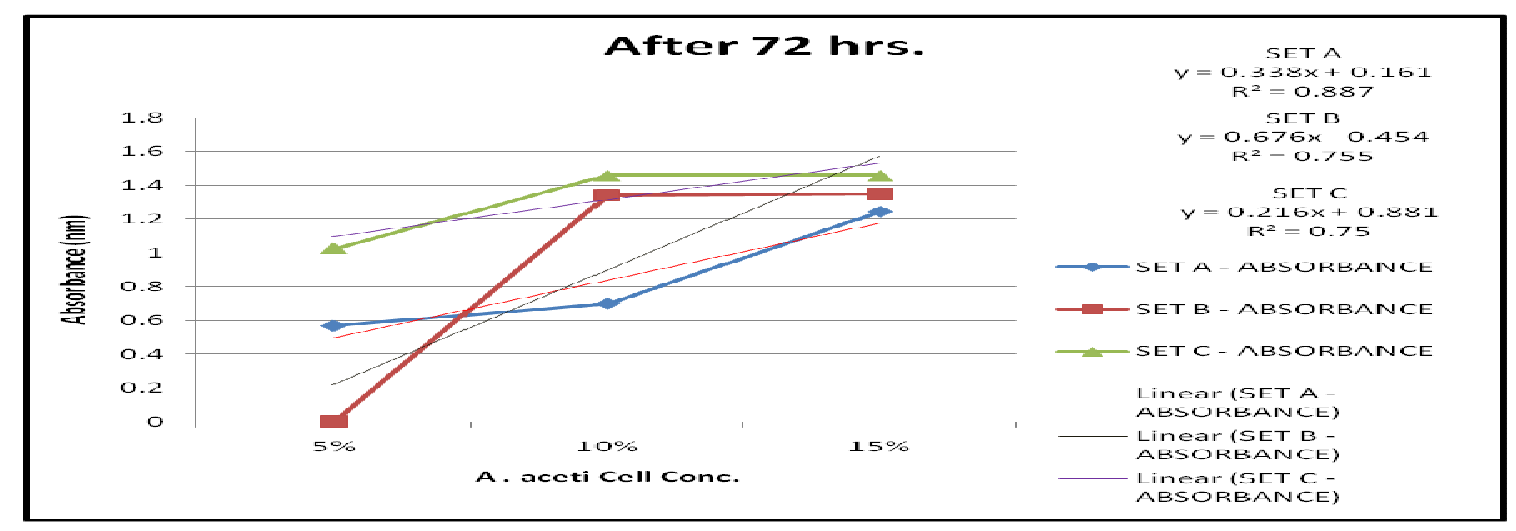

Chart-8: Effect Of Different A. aceti Cell Concentration On Optical Density Of Samples Set A, Set B, Set C After 72 Hrs.

The result of this study indicated that Acetobactor aceti with good fermentation attributes, which may enhance total acidity and minimize cost of production, could be obtained vinegar from banana alcohol.Acetic acid takes into account that other organic acids are present in vinegar at negligible quantities. It is possible to suppose that total acidity is a good indicator of the acetic acid concentration.

In this study, the physicochemical properties ( $\mathrm{pH}, \mathrm{OD}$ ) and acetic acid content of banana vinegar were analyzed. After fermentation, the vinegar has found a color of pale yellow. The results showed that acetic acid concentrations increased with an increase in inoculum level examined. A highest acetic acid concentrations of $4.67 \%$ and $4.62 \%$ were observed at the 15 and $10 \%$ inoculum level, respectively for highest alcohol contained sample (SET A). It was found from the graph (Chart-8), optical density or bacterial growth increased with an increase in inoculum level at the same time.

Acetic acid fermentation was successfully completed using banana juice. Most of the total sugar was converted to acetic acid via ethanol. Evaporation of volatile compounds including ethanol, acetaldehyde as well as acetic acid during the acetic fermentation process is one of the main causes of lowered concentration of acetic acid.

\subsection{STATISTICAL OPTIMIZATION TECHNIQUE}

Response surface methodology is an empirical modeling technique used to evaluate the relationship between a set of controllable experimental facts and observed values. The response surface methodologies involving central composite designs have been successfully applied to evaluate the effect of alcohol content, time, inoculum volume(A.aceti cell conentration) on titrable acidity $\%$ and optical density for vinegar fermentation by Acetobactor sp. (MTCC 2623).

Table-7 shows the results obtained from the central composite design regarding the studied variables: the concentrations of cell (A aceti), alcohol content \%, time using the isolated Acetobactor sp. for the production of vinegar. The analysis of variance (ANOVA) of the quadratic regression model demonstrates that the model is highly significant. The correlation measures for the estimation of the regression equation are the multiple correlation coefficient (R) and determination coefficient $\left(\mathrm{R}^{2}\right)$. The closer the value of $\mathrm{R}$ to 1 , the better is the correlation between the observed value and the predicted values.

The 3D response surface plot is a graphical representation of the regression equation. It is plotted to understand the interaction of the variables and locate the optimal level of each variable for maximal response. Each response surface plotted for acetic acid production represents the different combinations of two test variables at one time while maintaining the other variable at the zero level. The graphic representation of response surface shown in Fig-3 \& Fig.-4 helps to visualize the effects of alcohol content $\%$ and inoculum volume $\%$. 

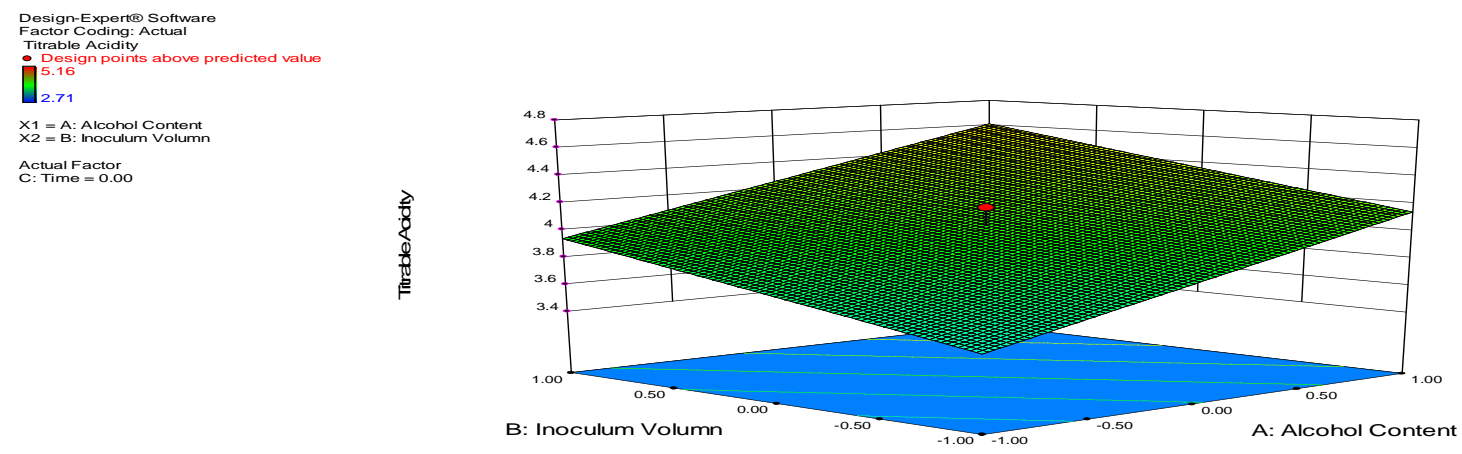

Fig-3: Response Surface Plot For Titrable Acidity \%

Table-7 Coded and Uncoded Full Factorial Central Composite Design

\begin{tabular}{|c|c|c|c|c|c|c|c|c|}
\hline \multirow[t]{2}{*}{ RUN } & \multicolumn{2}{|c|}{$\begin{array}{c}\text { ALCOHOL CONTENT } \\
\%\end{array}$} & \multicolumn{2}{|c|}{$\begin{array}{l}\text { INOCULUM } \\
\text { VOLUME \% }\end{array}$} & \multicolumn{2}{|c|}{ TIME IN HRS. } & \multirow{2}{*}{$\begin{array}{c}\text { RESPONSE } \\
\text { 1: } \\
\text { TITRABLE } \\
\text { ACIDITY \% }\end{array}$} & \multirow{2}{*}{$\begin{array}{c}\text { RESPONSE } 2 \text { : } \\
\text { OPTICAL } \\
\text { DENSITY }\end{array}$} \\
\hline & $\begin{array}{l}\text { CODED } \\
\text { VALUE }\end{array}$ & $\begin{array}{l}\text { ACTUAL } \\
\text { VALUE }\end{array}$ & $\begin{array}{l}\text { CODED } \\
\text { VALUE }\end{array}$ & $\begin{array}{l}\text { ACTUAL } \\
\text { VALUE }\end{array}$ & $\begin{array}{l}\text { CODED } \\
\text { VALUE }\end{array}$ & $\begin{array}{l}\text { ACTUAL } \\
\text { VALUE }\end{array}$ & & \\
\hline 1 & 1.00 & 7.77 & -1.00 & 5 & 1 & 72 & 4.52 & 0.569 \\
\hline 2 & 0.00 & 7.47 & 0.00 & 10 & 0 & 48 & 4.17 & 1.316 \\
\hline 3 & 1.00 & 7.77 & 0.00 & 10 & -1 & 24 & 3.79 & 1.065 \\
\hline 4 & 0.00 & 7.47 & 0.00 & 10 & 0 & 48 & 4.17 & 1.316 \\
\hline 5 & -1.00 & 6.29 & -1.00 & 5 & -1 & 24 & 2.73 & 1.001 \\
\hline 6 & 0.00 & 7.47 & 0.00 & 10 & 1.68 & 72 & 5.16 & 2.022 \\
\hline 7 & 1.00 & 7.77 & -1.00 & 5 & -1 & 24 & 3.66 & 0.384 \\
\hline 8 & 1.00 & 7.77 & 1.00 & 15 & 1 & 72 & 4.67 & 1.245 \\
\hline 9 & 0.00 & 7.47 & 0.00 & 10 & 0 & 48 & 4.17 & 1.316 \\
\hline 10 & 1.68 & 7.77 & 0.00 & 10 & 0 & 48 & 4.93 & 1.259 \\
\hline 11 & 0.00 & 7.47 & 0.00 & 10 & 0 & 48 & 4.17 & 1.316 \\
\hline 12 & 0.00 & 7.47 & 0.00 & 10 & 0 & 48 & 4.17 & 1.316 \\
\hline 13 & -1.00 & 6.29 & -1.00 & 5 & 1 & 72 & 4.3 & 1.026 \\
\hline 14 & 0.00 & 7.47 & 0.00 & 10 & 0 & 48 & 4.17 & 1.316 \\
\hline 15 & -1.00 & 6.29 & 1.00 & 15 & 1 & 72 & 4.37 & 1.459 \\
\hline 16 & -1.68 & 6.29 & 0.00 & 10 & 0 & 48 & 3.43 & 0.765 \\
\hline 17 & -1.00 & 6.29 & 1.00 & 15 & -1 & 24 & 3.19 & 1.426 \\
\hline 18 & 0.00 & 7.47 & 1.68 & 15 & 0 & 48 & 4.88 & 2.006 \\
\hline 19 & 0.00 & 7.47 & 0.00 & 10 & -1.68 & 24 & 2.71 & 0.628 \\
\hline 20 & 0.00 & 7.47 & -1.68 & 5 & 0 & 48 & 3.45 & 0.325 \\
\hline
\end{tabular}

Table- 8 shows the results of the second-order response surface models for titrable acidity in the form of analysis of variance (ANOVA). The regression equation demonstrated that titrable acidity was an empirical function of test variables in coded units.

The Model F-value of 13.05 implies the model is significant. There is only a $0.02 \%$ chance that a"Model F-Value" this large could occur due to noise. Values of "Prob > F" less than 0.0500 indicate model terms are significant.In this case A, B, C are significant model terms. Values greater than 0.1000 indicate the model terms are not significant. If there are many insignificant model terms (not counting those required to support hierarchy), model reduction may improve the model. Here the value of $\mathrm{R}$ indicates a high degree of correlation between the observed and the predicted values. The value of 
the determination coefficient $\left(\mathrm{R}^{2}=0.9216\right)$ being a measure of goodness of fit to the model, indicates that $7.84 \%$ of the total variations are not explained by the model. The adjusted $\mathrm{R}^{2}$ value $(0.8510)$ is also high, making the model very significant. The coefficient of variation (CV) indicates the degree of precision with which the treatment is compared. Usually, the higher the value of $\mathrm{CV}$, the lower is the reliability of the experiment. Here the low value of CV \% ( 6.50 ) indicates a greater reliability of the experiments performed.
The "Pred R-Squared" of 0.4009 is not as close to the "Adj RSquared" of 0.8510 as one might normally expect. This may indicate a large block effect or a possible problem with model and/or data. Things to consider are model reduction, response transformation, outliers, etc."Adeq Precision" measures the signal to noise ratio. A ratio greater than 4 is desirable. The ratio of 12.932 indicates an adequate signal. This model can be used to navigate the design space.

Table-8: ANOVA for Response Surface Quadratic Model On TA\%

\begin{tabular}{|c|c|c|c|c|c|}
\hline SOURCE & $\begin{array}{c}\text { SUM OF } \\
\text { SQUARES }\end{array}$ & $\begin{array}{l}\text { DEGREE OF } \\
\text { FREEDOM }\end{array}$ & $\begin{array}{c}\text { MEAN } \\
\text { SQUARE }\end{array}$ & F VALUE & $\begin{array}{l}\text { P-VALUE } \\
\text { PROB > F }\end{array}$ \\
\hline MODEL & 8.10 & 9 & 0.90 & 13.05 & $\begin{array}{c}<0.0002 \\
\text { SIGNIFICANT }\end{array}$ \\
\hline $\begin{array}{l}\text { A-ALCOHOL } \\
\text { CONTENT }\end{array}$ & 1.53 & 1 & 1.53 & 22.20 & 0.0008 \\
\hline $\begin{array}{l}\text { B-INOCULUM } \\
\text { VOLUMN }\end{array}$ & 0.76 & 1 & 0.76 & 10.97 & 0.0078 \\
\hline C-TIME & 5.43 & 1 & 5.43 & 78.71 & $<0.0001$ \\
\hline $\mathbf{A B}$ & 7.813E-003 & 1 & 7.813E-003 & 0.11 & 0.7434 \\
\hline $\mathbf{A C}$ & 0.13 & 1 & 0.13 & 1.85 & 0.2038 \\
\hline $\mathbf{B C}$ & 0.017 & 1 & 0.017 & 0.25 & 0.6292 \\
\hline $\mathbf{A}^{2}$ & 0.018 & 1 & 0.018 & 0.26 & 0.6191 \\
\hline $\mathbf{B}^{2}$ & 0.024 & 1 & 0.024 & 0.35 & 0.5685 \\
\hline $\mathrm{C}^{2}$ & 0.21 & 1 & 0.21 & 3.12 & 0.1080 \\
\hline RESIDUAL & 0.69 & 10 & 0.069 & & \\
\hline LACK OF FIT & 0.69 & 5 & 0.14 & & \\
\hline PURE ERROR & 0.000 & 5 & 0.000 & & \\
\hline $\begin{array}{c}\text { CORRECTED } \\
\text { TOTAL }\end{array}$ & 8.79 & 19 & & & \\
\hline
\end{tabular}

Table-9: R value for model

\begin{tabular}{|c|c|c|c|}
\hline Std. Dev. & 0.26 & R-Squared & 0.9216 \\
Mean & 4.04 & Adj R-Squared & 0.8510 \\
C.V. \% & 6.50 & Pred R-Squared & 0.4009 \\
PRESS & 5.27 & Adeq Precision & 12.932 \\
\hline
\end{tabular}

Table-10: Coefficients in Terms of Actual

\begin{tabular}{|c|c|}
\hline COEFFICIENT FACTOR & ESTIMATE \\
\hline Intercept & 4.18 \\
\hline A- Alcohol Content & 0.33 \\
\hline B- Inoculum Volumn & 0.24 \\
\hline C- Time & 0.63 \\
\hline AB & -0.031 \\
\hline AC & -0.13 \\
\hline BC & -0.046 \\
\hline A2 & -0.035 \\
\hline B2 & -0.041 \\
\hline C2 & -0.12 \\
\hline
\end{tabular}




\section{Final Equation in Terms of Coded Factors:}

Titrable Acidity $=+4.18+0.33 \times \mathrm{A}+0.24 \times \mathrm{B}+0.63 \times$ $\mathrm{C}-0.031 \times \mathrm{AB}-0.13 \times \mathrm{AC}-0.046 \times \mathrm{B}-0.035 \times \mathrm{A}^{2}-0.041$ $\mathrm{x} \mathrm{B}^{2}-0.12 \times \mathrm{C}^{2}$

Final Equation in Terms of Actual Factors:

Titrable Acidity $=+4.17597+0.33483 \times$ Alcohol Content + $0.23541 \times$ Inoculum Volumn +0.63048 x Time -0.031250 x Alcohol Content x Inoculum Volumn - 0.12625 x Alcohol Content $\mathrm{x}$ Time - $0.046250 \mathrm{x}$ Inoculum Volumn $\mathrm{x}$ Time -

$0.035490 \times$ Alcohol Content ${ }^{2}-0.040793$ x Inoculum

Volumn ${ }^{2}-0.12211 \times$ Time $^{2}$

Response surface study was made between Titrable Acidity \% of acetic acid fermentation against inoculum volume and alcohol content keeping time of fermentation at " 0 " coded level, i.e. , $48 \mathrm{hrs}$.
Now the 3D response surface study showed that alcohol content and inoculum level had a positive effect on TA \% of fermentation broth. But no clear experimental zone of optimum could be obtained. So the optimun was a suddle point within our experimental zone. Maximun value of Titrable Acidity \% was obtained at $4.67 \%$ for $72 \mathrm{hrs}$. with alcohol content $7.77 \%$ and yeast cell inoculation level $15 \%$. From this study, we can conclude that the TA\% was independent of alcohol concentration, but inoculum volume had a positive effect both on the TA $\%$ and the final cell growth.

The result of second - order response surface model (same for coded and uncoded test variables) fitting in the form of analysis of variance (ANOVA) is shown in Table- 11. The regression equation demonstrated that optical density was an empirical function of test variables in coded units.

Table-11: ANOVA for Response Surface Quadratic Model On OD

\begin{tabular}{|c|c|c|c|c|c|}
\hline SOURCE & $\begin{array}{c}\text { SUM OF } \\
\text { SQUARES }\end{array}$ & $\begin{array}{c}\text { DEGREE OF } \\
\text { FREEDOM }\end{array}$ & $\begin{array}{c}\text { MEAN } \\
\text { SQUARE }\end{array}$ & F VALUE & $\begin{array}{c}\text { P-VALUE PROB } \\
>\text { F }\end{array}$ \\
\hline MODEL & 2.84 & 9 & 0.32 & 2.95 & $\begin{array}{c}0.0536 \text { not } \\
\text { SIGNIFICANT }\end{array}$ \\
\hline $\begin{array}{c}\text { A-ALCOHOL } \\
\text { CONTENT }\end{array}$ & 0.048 & 1 & 0.048 & 0.45 & 0.5165 \\
\hline $\begin{array}{l}\text { B-INOCULUM } \\
\text { VOLUMN }\end{array}$ & 1.86 & 1 & 1.86 & 17.35 & 0.0019 \\
\hline C-TIME & 0.56 & 1 & 0.56 & 5.22 & 0.0454 \\
\hline AB & 0.031 & 1 & 0.031 & 0.28 & 0.6052 \\
\hline $\mathrm{AC}$ & 0.011 & 1 & 0.011 & 0.11 & 0.7509 \\
\hline BC & $8.000 \mathrm{E}-006$ & 1 & $8.000 \mathrm{E}-006$ & $7.471 \mathrm{E}-005$ & 0.9933 \\
\hline $\mathbf{A}^{2}$ & 0.27 & 1 & 0.27 & 2.50 & 0.1452 \\
\hline $\mathbf{B}^{2}$ & 0.097 & 1 & 0.097 & 0.90 & 0.3644 \\
\hline $\mathrm{C}^{2}$ & 9.382E-003 & 1 & $9.382 \mathrm{E}-003$ & 0.088 & 0.7733 \\
\hline RESIDUAL & 1.07 & 10 & 0.11 & & \\
\hline LACK OF FIT & 1.07 & 5 & 0.21 & & \\
\hline PURE ERROR & 0.000 & 5 & 0.000 & & \\
\hline $\begin{array}{c}\text { CORRECTED } \\
\text { TOTAL }\end{array}$ & 3.91 & & & & \\
\hline
\end{tabular}

The Model F-value of 2.95 implies there is a $5.36 \%$ chance that a "Model F-Value" this large could occur due to noise.Values of "Prob > F" less than 0.0500 indicate model terms are significant. In this case $\mathrm{B}, \mathrm{C}$ are significant model terms. Values greater than 0.1000 indicate the model terms are not significant.If there are many insignificant model terms (not counting those required to support hierarchy), model reduction may improve the model.
Table-12 : $\mathrm{R}$ value for model

\begin{tabular}{|c|l|c|c|}
\hline Std. Dev & 0.33 & $\begin{array}{c}\text { R- } \\
\text { Squared }\end{array}$ & 0.7264 \\
\hline Mean & 1.15 & $\begin{array}{c}\text { Adj R- } \\
\text { Squared }\end{array}$ & 0.4802 \\
\hline C.V. \% & 28.35 & $\begin{array}{c}\text { Pred R- } \\
\text { Squared }\end{array}$ & -1.0778 \\
\hline PRESS & 8.13 & $\begin{array}{c}\text { Adeq } \\
\text { Precision }\end{array}$ & 5.884 \\
\hline
\end{tabular}


A negative "Pred R-Squared" implies that the overall mean is a better predictor of the response than the current model."Adeq Precision" measures the signal to noise ratio. A ratio greater than 4 is desirable. The ratio of 5.884 indicates an adequate signal. This model can be used to navigate the design space.The coefficient of determination $\left(\mathrm{R}^{2}\right)$ was 0.7264 , indicating that $72.64 \%$ of the variability in the response could be explained by the model. The adjusted determination coefficient (adj. $R^{2}=0$. 4802) was also not satisfactory for confirming the significance of the model. Fig-4 displays the surface response plot of the model equation.

Table-13 : Coefficients in Terms of Actual

\begin{tabular}{|c|c|}
\hline COEFFICIENT FACTOR & ESTIMATE \\
\hline Intercept & 1.32 \\
\hline A-Alcohol Content & -0.060 \\
\hline B- Inoculum Volumn & 0.37 \\
\hline $\boldsymbol{C}$ - Time & 0.20 \\
\hline $\boldsymbol{A B}$ & 0.062 \\
\hline $\boldsymbol{A C}$ & 0.038 \\
\hline $\boldsymbol{B C}$ & $1.000 \mathrm{E}-003$ \\
\hline $\boldsymbol{A}^{\mathbf{2}}$ & -0.14 \\
\hline $\boldsymbol{B}^{\mathbf{2}}$ & -0.082 \\
\hline $\boldsymbol{C}^{\mathbf{2}}$ & -0.026 \\
\hline
\end{tabular}

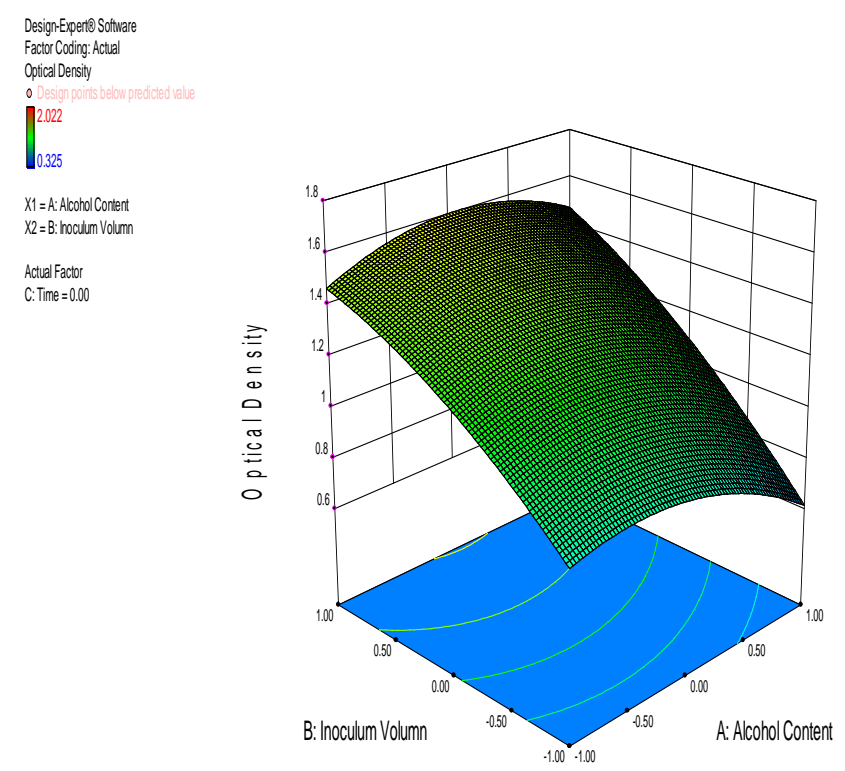

Fig-4: Response surface plot showing the effect of alcohol content and inoculum volume on optical density
The observed values are the experimentally obtained values and the predicted values were calculated based on the respective model equation for each experimental run. There was a good coordination between the observed and the predicted values in models. Regression equation of the linear model was analyzed using 3D response surface plots, which help to understand the effect of alcohol content and their range of optimum concentrations required for optical density in vinegar fermentation. 3D response surface plots were obtained by plotting the response (OPTICAL DENSITY) on the $\mathrm{Y}$-axis against two variables (alcohol content and A.aceti cell concentration level) while keeping other variable time at '0' level.

Response surface study was made between optical density of acetic acid fermentation against inoculum volume and alcohol content keeping time of fermentation at " 0 " coded level, i.e., $48 \mathrm{hrs}$. It was clear that at a particular alcohol content level, the optical density of fermentation increased with increase in inoculum level.

Now the 3D response surface study showed that no clear experimental zone of optimum could be obtained. So the optimun was a suddle point within our experimental zone. The optimization of the analyzed responses demonstrated that Maximun value of optical density was obtained at 1.459 for 72 hrs. with alcohol content $6.29 \%$ and A.aceti cell inoculation level $15 \%$. The goodness of fit of the model was verified by the determination coefficient $\left(R^{2}\right)$. In this study, bacterial growth had been increased significantly using statistical optimization techniques.

\section{CONCLUSIONS}

As a result, this study recommended that the vinegar must be subjected to sensory analysis, descriptive and consumer acceptance, for further evaluation and to investigate the amount of toxic compounds in banana vinegar and to report of isolation and identification of an Acetobacter strain.

Moreover, this study encouraged that the further development of this study by addition of some spices and food additives and by application of new principles discovered, aside from extending the fermentation time and also looking for strains with high vinegar production as well as suitable tolerance against high ethanol concentrations and production temperature.

\section{REFERENCES}

[1] Adams, M.R..1980. The small-scale production of vinegar from bananas. Tropical Product Institute, 56/62 Grays Inn Road, London

[2] Frazier, W.C. \& D.C. Westhoff.(1988).Food Microbiology.4th ed. New York: McGraw-Hill Book, Co. 
[3] Rumpai Gaensakoo, Busaba Tharasena and Charunee Thipayamart, Vinegar Production from Yam Bean Using Yeast and Acetobacter aceti 102 World Academy of Science, Engineering and Technology 712010 African Journal of Biotechnology Vol. 10(18), pp. 3608-3615, 2 May, 2011 Banana Breeding: Progress and Challenges,By Michael Pillay, Abdou Tenkouano, Abdou Tenkouano

[4] C.J.B. DE LIMA et al.: Lactic Acid Production Optimization, Food Technol. Biotechnol. 48 (2) 175181 (2010)

[5] S. GHOSH and T. SWAMINATHAN, Optimization of Extractive Fermentation, Chem. Biochem. Eng. Q. 17 (4) 319-325 (2003)

[6] Box, E.P. George, Hunter, J. Stuart, and Hunter, G. William. 2005. Statistics for Experiments. New Jersey: John Willey and Sons, Inc. Oehlert, Gary W. 2000. Design and analysis of experiments: Response surface design. New York: W.H. Freeman and Company

[7] Allgeier RJ, Hildebrandt FM. 1960. Newer developments in vinegar manufacture.Adv. Appl. Microbiol 11:163-181. Agnez-Lima LF, Di Mascio P, Napolitano RL, Fuchs RPP, Menck CFM. 1999. Mutation spectrum induced by singlet oxygen in Escherichia coli deficient in exonuclease III. Photochem. Photobiol 70:505-511.

[8] uchanan RE, Gibbons NE. 1974. Family III: Bergey's manual of determinativebacteriology. 8th ed. Baltimore: Williams and Wilkins Co. p 251-253.

[9] Canning A. 1985. Vinegar Brewing. Journal of Food Sci Sept/ Oct: 20-21.

[10] Carnacini A, Gerbi V, Zeppa G. 1992. Rapid extraction of volatile compounds inwine and vinegar using extrelut resin. Italian Journal of Food Science 4:259267.

[11] Chukwu U, Cheryan M. 1996. Concentration of vinegar by electrodialysis. Journal ofFood Science 61: 12231226.

[12] Conner HA, Allgeier RJ. 1976. Vinegar: its history and development. Adv. Appl. Microbiol 20: 81-133.

[13] Crisco Company. 1 Strawberry Lane Orrville, Ohio 44667 .2005 . http://www.crisco.com/basics/all_about/vinegar.asp.

[14] Cruess WV. 1958. Commercial fruit and vegetable products: Chapter 21 - Vinegarmanufacture. 1st ed. New York: McGraw-Hill Book Company, Inc. p 681707.

[15] M. FORSTER et al.: Distribution of Nutrients in Edible Banana Pulp, Food Technol. Biotechnol. 41 (2) 1671712003

[16] Beheshti Maal Keivan, hafiei Rasoul and Kabiri Noushin Production of Apricot Vinegar Using an Isolated Strain from IranianApricot Acetobacter , World Academy of Science, Engineering and Technology 712010
[17] Ndoye, B., L. Cleenwerck, K. Engelbeen, R. DuboisDauphin, A.T. Guiro, S.V. Trappen, A. Willems and P. Thonart, 2007. Acetobacter senegalensis sp. nov., a thermotolerant acetic acid bacterium isolated in Senegal (sub-Saharan Africa) from mango fruit (Mangifera indica L.).Int. J. Syst. Evol. Microbiol., 57: 1576-1581.

[18] Beheshti Maal, K. and R. Shafiei, 2010. Isolation and characterization of an Acetobacter strain from Iranian white-red cherry as a potential strain for cherry vinegar production in microbial biotechnology. Asian J. Biotechnol., 1: 53-59.

[19] A statistical program package, Design Expert (version 8.0.7.1., Start-Ease Inc., Minneapolis, MN) 